\title{
Small molecule receptor tyrosine kinase inhibitor of platelet-derived growth factor signaling (SU95 I 8) modifies radiation response in fibroblasts and endothelial cells
} Minglun Li* ${ }^{* 1,2,5}$, Gong Ping ${ }^{1,2}$, Christian Plathow ${ }^{2,6}$, Thuy Trinh ${ }^{1,2}$, Kenneth E Lipson ${ }^{4}$, Kai Hauser ${ }^{1,2,7,8}$, Robert Krempien ${ }^{3}$, Juergen Debus ${ }^{3}$, Amir Abdollahi1,2 and Peter E Huber ${ }^{1,2}$

Address: ${ }^{1}$ Department of Radiation Oncology, German Cancer Research Centre (DKFZ), Heidelberg, Germany, ${ }^{2}$ University of Heidelberg Medical School, Heidelberg, Germany, ${ }^{3}$ Department of Clinical Radiology, University Hospital Heidelberg, Germany, ${ }^{4}$ SUGEN, Inc., South San Francisco, California 94080-4811, USA, ${ }^{5}$ Department of Radiation Oncology, University Hospital Tuebingen, Germany, ${ }^{6}$ Department of Diagnostic Radiology, University Hospital Tuebingen, Germany, ${ }^{7}$ Institucio Catalana de Recerca i Estudis Avancats (ICREA), Barcelona, Spain and ${ }^{8}$ Department of Mathematics, University of California, Berkeley, CA, USA

Email: Minglun Li* - minglun.li@gmail.com; Gong Ping - gongping8878@yahoo.com; Christian Plathow - c.plathow@dkfz.de; Thuy Trinh - trinhsylvia@med.uni-heidelberg.de; Kenneth E Lipson - ken-lipson@sugen.com; Kai Hauser - k.hauser@dkfz.de; Robert Krempien - Robert.krempien@med.uni-heidelberg.de; Juergen Debus - juergen.debus@med.uni-heidelberg.de; Amir Abdollahi - a.amir@dkfz.de; Peter E Huber - p.huber@dkfz.de

* Corresponding author †Equal contributors

Published: 24 March 2006

BMC Cancer2006, 6:79 doi:10.1/86/1471-2407-6-79
Received: 12 September 2005

Accepted: 24 March 2006

This article is available from: http://www.biomedcentral.com/I47/-2407/6/79

(c) 2006Li et al; licensee BioMed Central Ltd.

This is an Open Access article distributed under the terms of the Creative Commons Attribution License (http://creativecommons.org/licenses/by/2.0), which permits unrestricted use, distribution, and reproduction in any medium, provided the original work is properly cited.

\begin{abstract}
Background: Several small receptor tyrosine kinase inhibitors (RTKI) have entered clinical cancer trials alone and in combination with radiotherapy or chemotherapy. The inhibitory spectrum of these compounds is often not restricted to a single target. For example Imatinib/Gleevec (primarily a bcr/abl kinase inhibitor) or SUII 248 (mainly a VEGFR inhibitor) are also potent inhibitors of PDGFR and other kinases. We showed previously that PDGF signaling inhibition attenuates radiation-induced lung fibrosis in a mouse model. Here we investigate effects of SU95 I8, a PDGFR inhibitor combined with ionizing radiation in human primary fibroblasts and endothelial cells in vitro, with a view on utilizing RTKI for antifibrotic therapy.
\end{abstract}

Methods: Protein levels of PDGFR- $\alpha /-\beta$ and phosphorylated PDGFR in fibroblasts were analyzed using western and immunocytochemistry assays. Functional proliferation and clonogenic assays were performed (i) to assess PDGFR-mediated survival and proliferation in fibroblasts and endothelial cells after SU95I8 (small molecule inhibitor of PDGF receptor tyrosine kinase); (ii) to test the potency und selectivity of the PDGF RTK inhibitor after stimulation with PDGF isoforms $(-A B,-A A,-B B)$ and VEGF+bFGF. In order to simulate in vivo conditions and to understand the role of radiation-induced paracrine PDGF secretion, co-culture models consisting of fibroblasts and endothelial cells were employed.

Results: In fibroblasts, radiation markedly activated PDGF signaling as detected by enhanced PDGFR phosphorylation which was potently inhibited by SU95 I8. In fibroblast clonogenic assay, SU95 18 reduced PDGF stimulated fibroblast survival by $57 \%$. Likewise, SU95 8 potently inhibited fibroblast and endothelial cell proliferation. In the co-culture model, radiation of endothelial cells and fibroblast cells substantially stimulated proliferation of non irradiated fibroblasts and vice versa. 
Importantly, the RTK inhibitor significantly inhibited this paracrine radiation-induced fibroblast and endothelial cell activation.

Conclusion: Radiation-induced autocrine and paracrine PDGF signaling plays an important role in fibroblast and endothelial cell proliferation. SU9518, a PDGFR tyrosine kinase inhibitor, reduces radiation-induced fibroblast and endothelial cell activation. This may explain therapeutic anticancer effects of Imatinib/Gleevec, and at the same time it could open a way of attenuating radiationinduced fibrosis.

\section{Background}

The development of fibrosis is a frequent side effect that may be caused by a variety of inductors. Fibrosis especially hampers cancer treatment such as radiotherapy and chemotherapy, thus severely limiting cancer therapy success. Furthermore, the development of fibrosis may reflect the integrative and interdependent roles of various cell compounds in tumor biology calling into question reductionist approaches focus on individual tumor cell compartment. Fibrosis occurs in many organs. Lung fibrosis for example may be caused by radiotherapy, chemotherapeutic drugs (such as bleomycin), amiodaron or, chemical substances (like asbestos fibers and silica particles, etc [1]). With the progression of the disease patients develop severe clinical symptoms limiting oxygenation of the blood and patients' survival. Treatment of fibrosis remains elusive given that the exact mediators and mechanisms involved in fibrogenesis are unknown [2,3].

Fibrosis is characterized by the excessive proliferation of mesenchymal cells (fibroblasts, myofibroblasts, and smooth muscle cells) and the subsequent deposition of extracellular matrix proteins [2]. Fibroblasts exhibit increased chemotaxis, proliferation, and extracellular matrix production in fibrotic lung and skin [2,4]. Cytokines such as platelet-derived growth factor (PDGF), transforming growth factor (TGF)- $\alpha$ and $-\beta$, interleukin (IL) $-1 \alpha$ and $-\beta$, and basic fibroblast growth factor (bFGF) have emerged as major stimulators of the fibroproliferative process induced by diverse stimuli such as ionizing radiation [5-7].

Here we focus on PDGF which has been implicated in a wide variety of pathological processes, including pulmonary fibrosis and skin fibrosis [8-10]. PDGF is a disulfidelinked dimer of two related polypeptide chains, designated $A, B, C$ and $D$, which are assembled as heterodimers (PDGF-AB) or homodimers (PDGF-AA, PDGF-BB, PDGF$\mathrm{CC}$ and PDGF-DD) [11]. PDGF exerts its biological activity by binding to structurally similar PDGF receptors (PDGFR- $\alpha$ and $-\beta$ ). It induces receptor dimerization and autophosphorylation of the receptor tyrosine kinase (RTK). Activated RTK phosphorylates numerous signaling molecules that initiate the intracellular signaling cascades leading to cell proliferation and survival [12]. These phos- phorylation-dependent interactions are essential for the activation of intracellular signaling pathways that can lead to tissue fibrosis. It seems reasonable to assume that blocking phosphorylation of PDGFR could be a way of preventing biological effects of this cytokine and thus fibrogenesis.

Recently, we have demonstrated this concept in vivo in a radiation-induced lung fibrosis model in mice by showing that inhibition of PDGF signaling functionally attenuates pulmonary fibrosis [13]. Here we analyze the underlying mechanistic cell effects in vitro with respect to the cellular pathway of RTK inhibition and to radiation for the PDGF/ PDGFR system in human primary fibroblasts and endothelial cells.

\section{Materials and methods \\ Endothelial and fibroblast cell cultures and reagents}

Primary isolated human dermal microvascular vein endothelial cells (HDMVEC, Promocell, Heidelberg, Germany) and primary isolated human fibroblasts (Promocell, Heidelberg, Germany) were cultured up to passage 6 . Cells were maintained in culture at $37^{\circ} \mathrm{C}$ with $5 \% \mathrm{CO}_{2}$ and $95 \%$ humidity in serum reduced (5\% fetus calf serum) modified promocell media (MPM) supplemented with $2 \mathrm{ng} / \mathrm{ml}$ vascular endothelial growth factor (VEGF) and $4 \mathrm{ng} / \mathrm{ml}$ basic fibroblast growth factor (bFGF). This combination of VEGF and bFGF optimized growth kinetics [14]. Human recombinant VEGF and bFGF proteins were purchased from Promocell.

\section{Western blotting}

Primary human lung fibroblasts were grown in modified media supplemented with 5\% fetus calf serum containing $2 \mathrm{ng} / \mathrm{ml}$ VEGF and $4 \mathrm{ng} / \mathrm{ml} \mathrm{bFGF}$ in $125 \mathrm{~cm}^{2}$ flasks. Cells were then treated either with $10 \mathrm{~Gy}$ or $5 \mu \mathrm{M}$ SU9518 exclusively or in combination with both (1 hour SU9518 incubation prior to radiation). $1 / 2$ hour after radiation fibroblasts were washed twice with ice-cold PBS, lysed with $250 \mu$ ice-cold cell lysis buffer ( 1 M Tris, $5 \mathrm{M} \mathrm{NaCl}$, 1 mM EDTA, 1 mM EGTA, pH 8.01). Lysates were kept on ice, and centrifuged at $4^{\circ} \mathrm{C}$ for 10 minutes at $13000 \mathrm{rpm}$. Supernatant was collected for western blotting assay as described [15]. Proteins were transferred from a polyacrylamide gel to a nitrocellulose membrane with a Mini- 
Trans-Blotter (100 V for 90 minutes) in transfer buffer. After transfer, non-specific binding sites were blocked for 1 hour with 5\% non-fat milk powder in TBST buffer (15 $\mathrm{mM} \mathrm{NaCl}, 1 \mathrm{mM}$ TRIS-HCl, 0.1\% Tween 20, pH 8.0) at room temperature. Each primary antibody (anti-PDGFR$\alpha$, anti-PDGFR- $\beta$ and anti-phosphorylated PDGFR- $\beta$, Cell Signaling Technology, Inc. Germany) was diluted in blocking buffer and incubated with the membrane overnight at $4^{\circ} \mathrm{C}$. After washing in TBST, the nitrocellulose membrane was incubated with horseradish peroxidaseconjugated antibody in blocking buffer at room temperature for 60 minutes. Antibody binding was determined using the enhanced chemiluminescence detection system according to the manufacturer's instructions. Exposures were recorded on hyperfilms for 10 seconds to 3 minutes.

\section{Immunocytochemistry}

Fibroblasts were cultured as in the western blotting assay. After trypsinization of fibroblasts in flasks, $20 \mu \mathrm{l}$ cell suspensions $\left(3 \times 10^{4}\right.$ cells $\left./ \mathrm{ml}\right)$ were seeded on slips and incubated for 24 hour at $37^{\circ} \mathrm{C}$ with $5 \% \quad \mathrm{CO}_{2}$ and $95 \%$ humidity. After treatments with radiation (10 Gy), SU9518 $(5 \mu \mathrm{M})$ or SU9518 + radiation (1 hour incubation with SU9518 prior radiation), fibroblasts were incubated $1 / 2,6,12$ or 24 hours in MPM. After stimulation fibroblasts were washed with phosphate-buffered saline (PBS) and fixed with methanol and acetone 5 minutes at $-20^{\circ} \mathrm{C}$ respectively. After washing with PBS, fibroblasts were permeabilized for 30 minutes with PBS containing 1\% tween-20 (Merck, Darmstadt, Germany), and blocked for 30 minutes with PBS blocking buffer (containing 5\% FBS with 1\% tween-20). The cells were incubated for 12 hours at $18-20^{\circ} \mathrm{C}$ in blocking buffer with 3 primary antibodies: anti-PDGFR- $\alpha$, anti-PDGFR- $\beta$ and anti-phosphorylated PDGFR- $\beta$ (Cell Signaling Technology, Inc. Germany). After washing with PBS, the cells were incubated for 1 hour at room temperature with 1:250 secondary antibodies, goat anti-mouse IgG (Alexa Fluor 488) or goat anti-rabbit IgG (Alexa Fluor 488), and mixed 1:200 with bromphenolblue (Sigma, St. Louis, USA) solution for cell nucleus staining. After further washing slides were mounted in Citifluor mounting medium and were examined with a fluorescence microscope (400X, software Openlab 3.1.4, Leica, DMIRB).

\section{Clonogenic survival assay}

To investigate the effects of SU9518 on clonogenic survival of fibroblast and endothelial cells, cells were plated with increasing numbers $\left(10^{2}\right.$ to $\left.5 \times 10^{4}\right)$ in $25 \mathrm{~cm}^{2}$ flasks. Cells were incubated with $0-10 \mu \mathrm{M}$ SU9518 in presence of $10 \mathrm{ng} / \mathrm{ml}$ PDGF-AB. Flasks were returned to the incubator for 14-17 days, after which they were stained with crystal violet (Sigma, Germany). Colonies were counted and the surviving percentage was determined for clonogenic survival after correcting for plating efficiency.

\section{Proliferation assay}

Cells were harvested by trypsinization at $37^{\circ} \mathrm{C}$ and neutralized with trypsin-neutralizing solution. A suspension of 50000 cells in MPM/DMEM was added to $25 \mathrm{~cm}^{2}$ flasks (Becton Dickinson, Heidelberg, Germany). Cells were incubated with SU9518 for 1 hour in cytokine-free medium at standard conditions and incubated for another 72 hours in final mediums (either with $10 \mathrm{ng} / \mathrm{ml}$ PDGF-AB, or with $2 \mathrm{ng} / \mathrm{ml}$ VEGF $+4 \mathrm{ng} / \mathrm{ml}$ bFGF). Cells were then dispersed in trypsin, resuspended, and counted in a coulter counter.

In fibroblasts, PDGF-isoform dependent proliferation assays were performed as follows: Fibroblasts were cultured and plated as in the clonogenic assay. Cells were incubated for 72 hours either with PDGF (-AA, -AB, -BB, each isoform in 2 and $10 \mathrm{ng} / \mathrm{ml}$ ) alone, or with additional administration of $5 \mu \mathrm{M}$ SU9518. Cells were then dispersed in trypsin, resuspended, and counted in a coulter counter.

\section{Co-culture model}

A proliferation assay in a co-culture model was used to assess the proliferation ability of cells in the upper compartments after irradiation of cells in the lower compartments with or without SU9518 treatment. Human dermal microvascular endothelial cells (HDMVECs) were grown in 24 well plates. At confluence, the media were changed. Cells were irradiated with $10 \mathrm{~Gy}$ using a $6 \mathrm{MeV}$ x-rays linear accelerator at a dose rate of $118 \mathrm{cGy} / \mathrm{min}$. Transwell inserts of upper compartments with a $0.6 \mu \mathrm{m}$ pore size were plated with 20,000 cells. In SU9518 treated groups and SU9518 + radiation groups, cells in upper compartments were preincubated with $5 \mu \mathrm{M}$ SU9518 for 1 hour. After selective irradiation of cells in lower compartments, transwells of upper compartments containing cells were transferred into the 24 well plates, incubated for 72 hours at standard conditions, then dispersed in trypsin, resuspended and counted. Three conditions were analyzed: (A) irradiated fibroblast cells in the lower compartment, as the chemotactic "agent" after radiation, and (non irradiated) fibroblasts in the upper compartment; (B) irradiated HDMVEC in the lower compartment and fibroblasts in the upper compartment; $(\mathrm{C})$ irradiated fibroblasts in the lower compartment and non irradiated HDMVEC in the upper compartment.

\section{Statistical analysis}

Statistical analyses were performed with a statistical analysis software system (Statistica 6.0). Student's t test was used to compare means. For multiple comparisons ANOVA was used with Fisher's least-significant difference method. P-values less than 0.05 were considered statistically significant. 
(a)

\begin{tabular}{|c|c|c|c|c|}
\hline & RT & SU9518 & SU9518+RT & Control \\
\hline PDGFR-a & $r=0$ & fort & $6=4$ & was? \\
\hline PDGFR- $\beta$ & & + & 100 & Earet \\
\hline p-PDGFR- $\beta$ & & notit & & 7108 \\
\hline$\beta$-Tubulin & 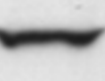 & $\sim$ & & \\
\hline
\end{tabular}

(b)

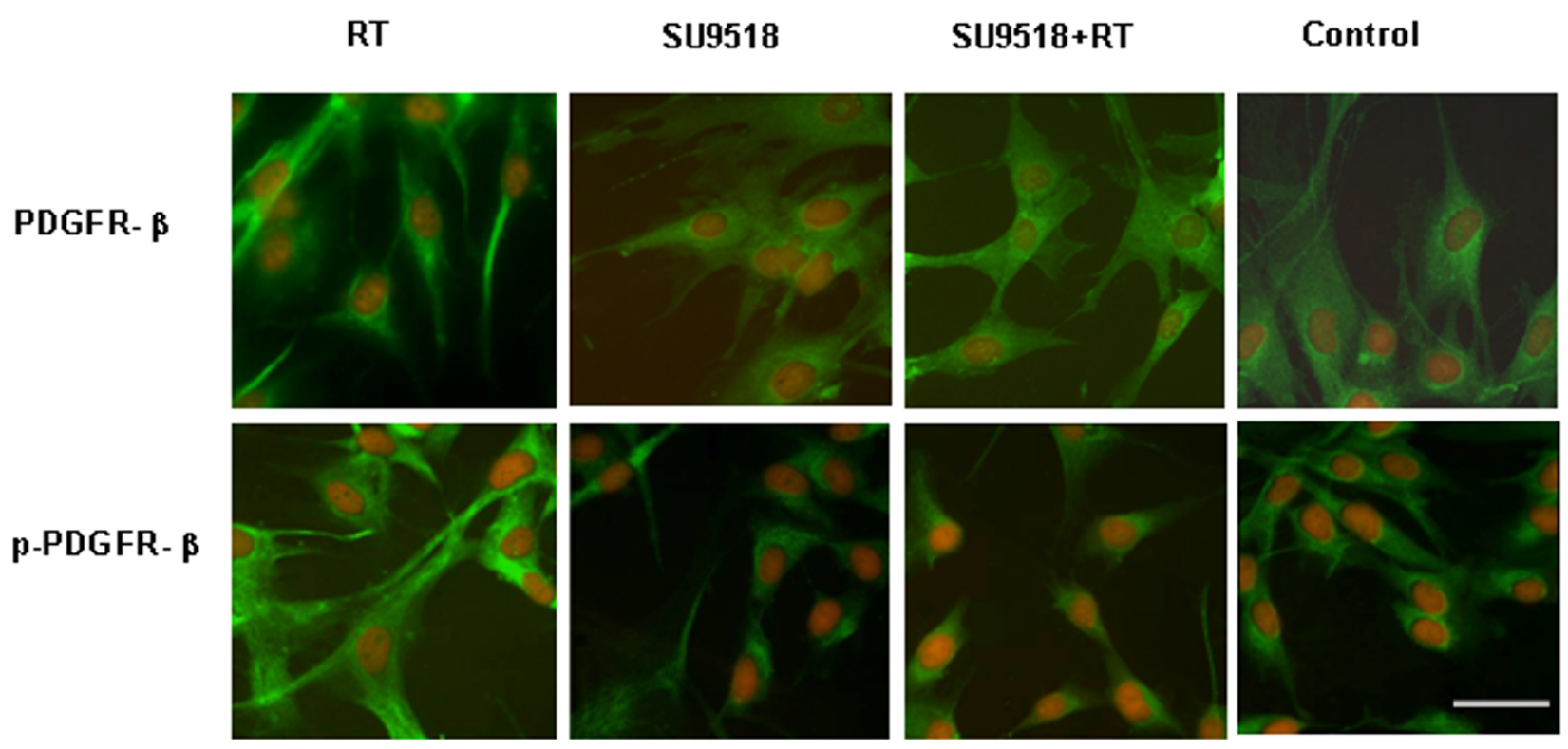

\section{Figure I}

(a) Western-blotting analysis of PDGFR- $\alpha /-\beta$ and phosphorylated PDGFR- $\beta$ (P-PDGFR- $\beta$ ). Human dermal fibroblast cells were treated with or without $5 \mu \mathrm{M}$ SU95I8 for I hour before $10 \mathrm{~Gy}$ irradiation. Whole cell lysates of fibroblasts were collected for protein content and separated by SDS-PAGE and transferred to nitrocellulose. The amount of PDGFR and phosphorylated PDGFR was visualized with anti-PDGFR- $\alpha$, anti-PDGFR- $\beta$ or anti-phosphorylated PDGFR- $\beta$ antibodies, respectively. Radiationinduced PDGFR phosphorylation was markedly inhibited by SU95I 8. (b) Immunocytochemistry of human primary dermal fibroblast cells. Fibroblasts were analyzed as untreated (control), after SU95 I 8 (5 $\mu \mathrm{M}$ ), irradiation (I0Gy) or combined SU95 I 8 and radiation treatment. The cells were incubated 6 hours post radiation and stained with the polyclonal rabbit anti-PDGFR- $\beta$ / anti-p-PDGFR- $\beta$ antibody followed by incubation with Alexa Fluor 488 goat anti-rabbit secondary antibody. For nuclear localization the cells were counterstained with propidium jodide (red color). Immunofluorescence staining for PDGFR- $\beta / P-P D G F R-$ $\beta$ was indicated by green fluorescence. Irradiation-induced phosphorylation of PDGFR- $\beta$ and that was substantially inhibited by SU9518. Scale bar presents $25 \mu \mathrm{m}$. 
(a)

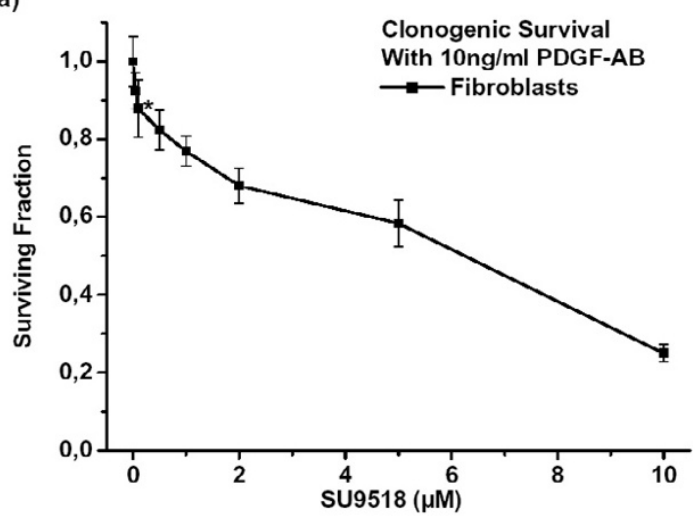

(b)

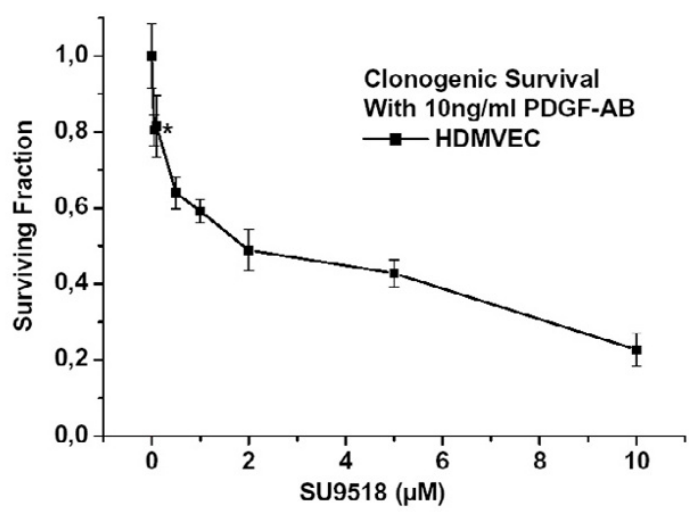

Figure 2

(a) Clonogenic survival assay of dermal fibroblasts. Fibroblast cells $\left(10^{2}\right.$ to $\left.5 \times 10^{4}\right)$ were incubated with $0-10 \mu \mathrm{M}$ SU95 I 8 in presence of $10 \mathrm{ng} / \mathrm{ml} \mathrm{PDGF-AB}$. Cultures were returned to the incubator for 14-17 days, after which they were stained with crystal violet (Sigma, Germany). Colonies were counted and the surviving percentage was determined for clonogenic survival after correcting for plating efficiency. Bars are means of 5 experiments \pm SD. (b) Clonogenic survival assay of human dermal microvascular endothelial cells (HDMVECs). Endothelial cells were treated with 0-10 $\mu \mathrm{M}$ SU95I 8 in the presence of $10 \mathrm{ng} / \mathrm{ml}$ PDGF-AB in the media. Surviving fraction was calculated based on the number of colonies counted after 14-17 days. Bars are means of 5 experiments \pm SD.

\section{Results}

\section{PDGFR protein regulation in fibroblasts}

To investigate the impact of radiation to PDGFR in fibroblasts and the effect of SU9518 on phosphorylation of PDGF RTK in fibroblasts after radiation, human dermal fibroblast cells were pre-treated with $5 \mu \mathrm{M}$ SU9518 one hour before $10 \mathrm{~Gy}$ irradiation and incubated for $30 \mathrm{~min}$ utes (Figure 1a). PDGFR levels as well as PDGFR phos- phorylation were determined by western-blotting using primary antibodies specific to PDGFR- $\alpha$, PDGFR- $\beta$ or phosphorylated PDGFR- $\beta$ (p-PDGFR- $\beta$ ), respectively. Irradiation stimulated overexpression of both PDGFR- $\alpha$ and $-\beta$ in fibroblasts, while expression of PDGFR- $\beta$ was more upregulated than PDGFR- $\alpha$. Moreover, irradiation resulted in significantly increased PDGFR- $\beta$ phosphorylation while SU9518 treatment particularly inhibited phosphorylation of PDGFR- $\beta$.

\section{Immunocytochemistry}

To investigate radiation-induced PDGF signaling in fibroblasts in the presence or absence of SU9518, immunocytochemistry analyses were performed at various time points $(1 / 2,1,6$ hours) after irradiation. Irradiation resulted in enhanced phosphorylation of PDGFR- $\beta$ (pPDGFR- $\beta$ ) in fibroblasts. Representative microscopic photos of fibroblasts with PDGFR- $\beta$ or p-PDGFR- $\beta$ staining are presented at time points $1 / 2$ and 6 hours after radiation, respectively (Fig. 2b). Importantly, the autophosphorylation of PDGFR- $\beta$ was markedly inhibited by $5 \mu \mathrm{M}$ SU9518, consistent with the results in western-blotting assays.

\section{Fibroblasts clonogenic survival}

In the clonogenic survival assay, stimulating effects of PDGF (-AB isoform, $10 \mathrm{ng} / \mathrm{ml}$ ) on fibroblast cells were examined in the absence or presence of SU9518 with increasing concentrations (Figure 2a). Inhibition of PDGF signaling by SU9518 reduced the clonogenic survival fraction of fibroblasts. The surviving fraction of fibroblasts was reduced by $10 \mu \mathrm{M}$ SU9518 to 0.23 fold (Figure 3), suggesting that PDGF played a role for the clonogenic survival of fibroblasts which in turn would explain why the small molecular RTK inhibitor SU9518 inhibits fibroblast clonogenic survival.

\section{Endothelial cell clonogenic survival}

In the clonogenic survival assay (Figure 3a), the inhibitory effects of SU9518 on human dermal microvascular endothelial cells (HDMVECs) were examined in the presence of PDGF (-AB isoform, $10 \mathrm{ng} / \mathrm{ml}$ ). Inhibition of PDGF signaling with SU9518 reduced the survival fraction of endothelial cells, which underscored the importance of the PDGF pathway for the survival of endothelial cells. For example, using $5 \mu \mathrm{M}$ SU9518, surviving fraction of endothelial cells decreased to $42 \%$ and further to $22 \%$ at $10 \mu \mathrm{M}$ SU9518. Thus the PDGF-mediated clonogenic survival of endothelial cells was significantly inhibited by the administration of SU9518 in a dose dependent manner.

\section{Endothelial cell proliferation}

To further evaluate the specificity of SU9518, its ability to inhibit PDGF-stimulated endothelial proliferation was 


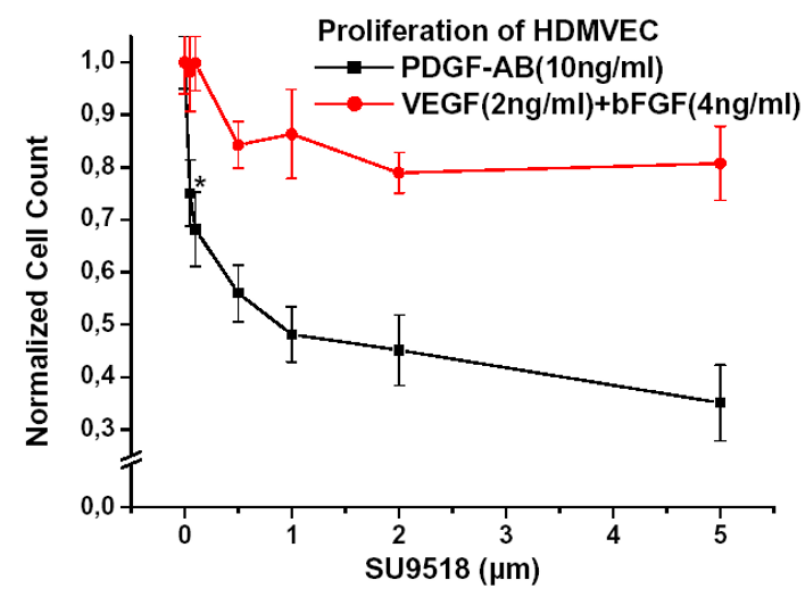

Figure 3

Proliferation assay of HDMVECs. Endothelial cells were plated in collagen l-coated flask and stimulated with $10 \mathrm{ng} / \mathrm{ml}$ PDGF (black line) or $2 \mathrm{ng} / \mathrm{ml} \mathrm{VEGF}+4 \mathrm{ng} / \mathrm{ml}$ bFGF (red line) in the absence or presence of SU95 18 with increasing concentration $(0.1,0.5, I, 2$ and $5 \mu \mathrm{M})$. 72 hours later cells were counted and normalized to respective controls without SU9518.

measured and compared with its inhibitory potency to endothelial proliferation stimulated by VEGF and bFGF. We found that SU9518 inhibited $10 \mathrm{ng} / \mathrm{ml}$ PDGF-induced endothelial proliferation with an IC50 of approximately 0.9 $\mu \mathrm{M}$. PDGF-induced proliferation was effectively blocked by SU9518, whereas endothelial proliferation stimulated by VEGF and bFGF was inhibited to a much lesser degree by SU9518 (Figure 2b). For example, the cell number reduction by $1 \mu \mathrm{M}$ SU9518 was 52\% after PDGF stimulation versus $13 \%$ after stimulation by VEGF and bFGF.

\section{PDGF-isoforms dependent fibroblasts proliferation}

Several PDGF-isoforms are found to stimulate different PDGFR subtypes. To further assess the effects of SU9518 we investigated the PDGF-isoforms dependent inhibition of fibroblast proliferation at $2 \mathrm{ng} / \mathrm{ml}$ or $10 \mathrm{ng} / \mathrm{ml}$ concentrations of various PDGF-isoforms. We found that SU9518 significantly inhibited fibroblast proliferation induced by all three PDGF-isoforms at a concentration of $5 \mu \mathrm{M}$ (Figure 4). The inhibitory potency of SU9518 to PDGF-AB and -BB appeared to be slightly greater than $\mathrm{AA}$, while that to PDGF-AB was the most pronounced among the three isoforms.

\section{Radiation-induced interactions between fibroblasts and endothelial cells}

To investigate the interactions between fibroblasts and endothelial cells a co-culture model was used. Irradiation
(10 Gy) of human dermal microvascular endothelial cells (HDMVECs) stimulated paracrine fibroblast proliferation (2.1 fold). Likewise, irradiation of fibroblast cells also stimulated fibroblast cells and endothelial cells in the non irradiated upper compartment up to 1.5 fold (Figure 5). Importantly, the paracrine fibroblast stimulation by either fibroblast or endothelial cells was markedly reduced with the administration of SU9518 by approximately 50\% (P< $0.001)$. Thus SU9518 could significantly inhibit the activation of radiation-induced direct and indirect fibroblast activation.

\section{Discussion}

In the context of fibrosis development in conventional cancer therapy, including radio- and chemotherapy, we studied here the effects of SU9518, a receptor tyrosine kinase inhibitor of PDGF signaling on human primary dermal fibroblasts and endothelial cells. We had previously shown that using this class of molecular targeted compounds - including SU9518 and Imatinib (Gleevec) as well as SU11657 (similar to SU11248, a compound currently in several clinical phase I and II anticancer trials) - can attenuate ionizing radiation-induced lung fibrosis in vivo if it is given either prior to or after radiation insult [13]. Here we investigate in vitro whether primary human endothelial and fibroblast cells are an important primary target of the RTK inhibitor in the context of PDGF signaling. We found that, in vitro, irradiation of fibroblasts and endothelium induced autocrine and paracrine PDGF expression. Functionally, the isolated irradiation of primary human endothelial cells stimulated proliferation in human fibroblasts in a co-culture model. Thus irradiation has effects which can be described as an indirect promotion of fibroblast survival and proliferation. Importantly, RTK inhibitors could effectively attenuate this paracrine radiation-induced activation by blocking autophosphorylation of PDGFR and by downregulation of PDGFR expression. Since fibroblasts are most likely key players in radiotherapy related fibrosis, and given the close correlation between PDGF signaling and fibroblasts activity (e.g. survival and proliferation), along with results in vivo [13] we conclude that fibroblasts may as well be a target of RTK inhibitors in the process of attenuating radiation-induced fibrogenesis in vivo.

This conclusion is in agreement with earlier reports showing that PDGF is a potent mitogen and chemoattractant for mesenchymal cells and also a chemoattractant for neutrophils and monocytes [16-18]. Similarly, several studies had reported that PDGF isoforms and their receptors were upregulated during pathologic fibroproliferative diseases in humans and in murine models by different types of impairment (e.g. radiation- [19,20]/bleomycin- [11] induced fibrosis, idiopathic pulmonary fibrosis [21]) vin- 


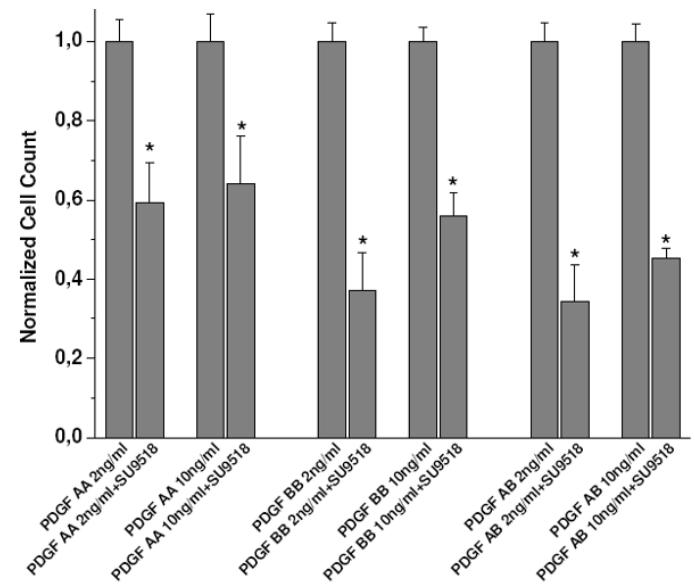

Figure 4

PDGF-isoform dependent fibroblast proliferation assay. Fibroblasts were stimulated by PDGF-isoforms (-AA, -BB and $-A B$ ) at $2 \mathrm{ng} / \mathrm{ml}$ or $10 \mathrm{ng} / \mathrm{ml}$ for 72 hours after I hour pretreatment with or without SU9518. SU95I8 inhibited all three isoforms stimulated proliferation of fibroblasts $(p<$ 0.05 ). The extent of inhibition was greater for PDGF-AB and $-B B$. Bars are means of 5 experiments \pm SD.

dicating the importance of the PDGF/PDGFR system in proliferative diseases.

PDGFR- $\beta$ has been suggested to be predominantly expressed in fibroblasts [12] in agreement with our data presented here. In addition, we found that PDGFR- $\beta$ was more upregulated after radiation in fibroblasts compared with PDGFR- $\alpha$ in both western blotting and immunocytochemistry assays. Others had shown that fibroblasts isolated from rat lungs over expressed PDGFR- $\beta$ with higher chemotactic response to PDGF-BB in vivo [20]. Although the ultimate mechanism of PDGFR overexpression remains unclear, we found ionizing radiation can upregulate PDGFR in fibroblasts. More importantly, for the ultimate goal of treating or preventing fibrosis in patients, we found that SU9518 attenuated the radiation-induced upregulation of PDGFR.

The best characterized mechanisms by which PDGF down-streaming signaling mediates cellular responses involve the activation of the ras/MAPK pathway, which can functionally increase cellular proliferation, and the PI3k/Akt pathway, which promotes cell survival in general tumor biology [22]. PDGF has also been shown to stimulate mitogenicity and chemotaxis of fibroblasts and smooth muscle cells [12]. In our fibroblast clonogenic and proliferation assays, inhibition of PDGF signaling by SU9518 significantly reduced the clonogenic survival fraction and the proliferation of fibroblasts, thus supporting the important role of PDGF signaling for fibroblasts survival. Moreover, PDGF has been shown to stimulate the production of several matrix molecules, such as collagen, fibronectin, and proteoglycan [23-25]. The resulting close correlation between PDGF/PDGFR and fibroblasts may explain the inhibitory effect of SU9518 to radiationinduced fibrosis [13].

To further evaluate the specificity of SU9518, its ability to inhibit cell proliferation stimulated by PDGF (-AB isoform) or combined VEGF and bFGF was measured, because these growth factors have been shown to induce similar signaling pathways, changes in gene expression, and cellular responses in mesenchymal cells [26].

Unresolved issues in fibrosis research inlclude the relative contribution of different cell types to the fibrotic development and the usefulness of acute anti-inflammatory drugs such as corticosteroids. A Cochrane review of corticosteroids in idiopathic lung fibrosis found no evidence that steroid treatment was of any benefit, in spite of repression of early inflammation [27]. Savikko et al demonstrated that cyclosporin A treatment cannot inhibit the expression of PDGF ligands and receptors, although it ameliorated the extent of inflammation [28]. This suggests the involvement of other cells besides acute inflammatory cells in the development of fibrosis. In vivo in lungs, the radiationinduced fibroproliferative process occurs within the microenvironment of the distal gas exchange units consisting of fibroblasts, epithelial cells $[29,30]$ and endothelial cells [31]. In agreement with our co-culture results, endothelial cells are described as potential sources of PDGF after radiation [6]. Epithelial cells do not express PDGF and PDGFR under physiological conditions. But expression of c-sis mRNA in epithelial cells has been reported in certain pathologic fibrotic states, such as in patients with idiopathic lung fibrosis [21].

SU9518 exerts its inhibitory effect by ATP-competitive inhibition of the catalytic activity of the tyrosine kinase after PDGFR activation [32]. Under normal conditions PDGF-AA induces $\alpha / \alpha$ receptor dimers, PDGF-AB induces $\alpha / \alpha$ and $\alpha / \beta$ receptor dimers and PDGF-BB induces all three receptor dimer combinations. Since SU9518 inhibited fibroblast proliferation activated by all three isoforms, it is conceivable that SU9518 can inhibit both PDGFR- $\alpha$ and $-\beta$.

Despite many investigations, the relative roles of most cytokines/growth factors in fibroproliferative diseases are not completely defined. For some of the putative key players such as TGF- $\beta$, IL- 1 , TNF- $\alpha$ and thrombin it has been reported that they may exert their profibrotic activities through a PDGF-dependent pattern [33-36]. One should keep in mind however that in the case of ionizing radia- 


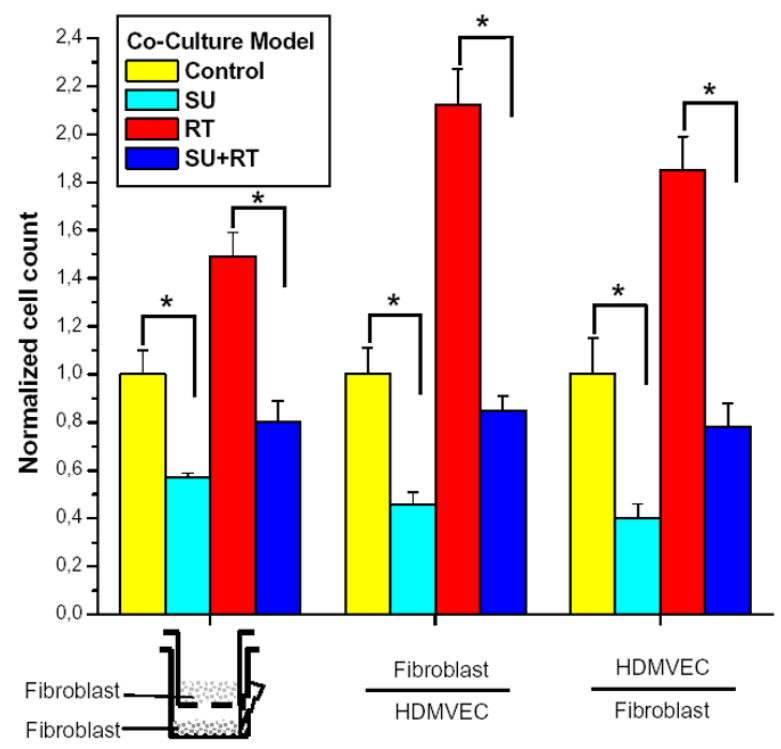

Figure 5

Co-culture experiments. Cells in lower compartments were selectively irradiated to induce paracrine proliferation of cells in upper compartments. Radiation (I0Gy) of endothelial cells (HDMVECs) and fibroblast cells stimulated fibroblast proliferation (RT) in upper compartments. The administration of SU95 I 8 significantly inhibited radiation-induced fibroblast proliferation. Likewise, irradiation of fibroblasts stimulated the proliferation of HDMVECs. The paracrine induction of endothelial cell proliferation was significantly inhibited by SU9518. The basal paracrine mitogenic stimulation of fibroblasts or endothelial cells in the upper compartment induced by co-culturing with non irradiated control cells in the lower compartment was also effectively inhibited by SU95 I 8 (all SU951 8 vs. control groups). Bars are mean \pm SD. In all figures asterisks indicate degree of statistical significance: *significant, $P<0.05$; **highly significant $P<0.01$.

tion the signaling cascades in cells are complex and the resulting regulations may well be described as a network of signaling [36-40]. Nevertheless, PDGF may be an important node in this network and thus a key cytokine responsible for the fibrotic development, suggesting that perturbation of the PDGF/PDGFR system could provide an effective means of inhibiting fibrosis.

\section{Conclusion}

Radiation-induced autocrine and paracrine PDGF signaling plays an important role in fibroblast and endothelial cell activation and proliferation. PDGFR tyrosine kinase inhibition reduces radiation-induced fibroblast activation. This data supports the notion that SU9518 might exert its antifibrotic activity in vivo via attenuation of PDGF signaling. These results warrant further studies investigating how tyrosine kinase inhibitors with anti-
PDGF property may attenuate cancer therapy related fibrosis in addition to their primary antitumoral activity.

\section{Competing interests}

The author(s) declare that they have no competing interests.

\section{Authors' contributions}

ML participated in performing experiments, in data analysis and in writing the manuscript. PG performed western blots and immunocytochemistry. CP participated in writing the manuscript. KEL participated in designing the study and in writing the manuscript. RK, KH and JD participated in writing the manuscript. TT performed the cell assays. AA and PEH designed the study, participated in data analyses and in writing the manuscript. All authors edited and acknowledged the final version of the manuscript.

\section{Acknowledgements}

This study was supported by the Research Program of the University of Heidelberg Medical School.

\section{References}

I. Lasky JA, Coin PG, Lindroos PM, Ostrowski LE, Brody AR, Bonner JC: Chrysotile asbestos stimulates platelet-derived growth factor-AA production by rat lung fibroblasts in vitro: evidence for an autocrine loop. Am J Respir Cell Mol Biol 1995, I 2: I62-I70.

2. Trott KR, Herrmann $T$, Kasper $M$ : Target cells in radiation pneumopathy. International Journal of Radiation Oncology*Biology*Physics 2004, 58:463-469.

3. Plathow C, Li M, Gong P, Zieher H, Kiessling F, Peschke P, Kauczor $\mathrm{HU}$, Abdollahi A, Huber PE: Computed tomography monitoring of radiation-induced lung fibrosis in mice. Invest Radiol 2004 , 39:600-609.

4. Davis AM, Gerrand C, Griffin A, O'Sullivan B, Hill RP, Wunder JS, Abudu A, Bell RS: Evaluation of clinical utility of BTC-2000 for measuring soft tissue fibrosis. International Journal of Radiation Oncology*Biology*Physics 2004, 60:286-294.

5. Gridley DS, Bonnet RB, Bush DA, Franke C, Cheek GA, Slater JD, Slater JM: Time course of serum cytokines in patients receiving proton or combined photon/proton beam radiation for resectable but medically inoperable non-small-cell lung cancer. Int J Radiat Oncol Biol Phys 2004, 60:759-766.

6. Zerwes HG, Risau W: Polarized secretion of a platelet-derived growth factor-like chemotactic factor by endothelial cells in vitro. J Cell Biol 1987, I 05:2037-204I.

7. Lindroos PM, Coin PG, Badgett A, Morgan DL, Bonner JC: Alveolar macrophages stimulated with titanium dioxide, chrysotile asbestos, and residual oil fly ash upregulate the PDGF receptor-alpha on lung fibroblasts through an IL-I beta-dependent mechanism. Am J Respir Cell Mol Biol 1997, I 6:283-292.

8. lida H, Seifert R, Alpers CE, Gronwald RG, Phillips PE, Pritzl P, Gordon K, Gown AM, Ross R, Bowen-Pope DF, Johson R: Plateletderived growth factor (PDGF) and PDGF receptor are induced in mesangial proliferative nephritis in the rat. Proc Natl Acad Sci USA I99।, 88:6560-6564.

9. Wilcox JN, Smith KM, Williams LT, Schwartz SM, Gordon D: Platelet-derived growth factor mRNA detection in human atherosclerotic plaques by in situ hybridization. J Clin Invest | 988, 82: I|34-I|43.

10. Rice AB, Moomaw CR, Morgan DL, Bonner JC: Specific inhibitors of platelet-derived growth factor or epidermal growth factor receptor tyrosine kinase reduce pulmonary fibrosis in rats. Am J Pathol 1999, I 55:213-221.

II. Zhuo Y, Zhang J, Laboy M, Lasky JA: Modulation of PDGF-C and PDGF-D expression during bleomycin-induced lung fibrosis. Am J Physiol Lung Cell Mol Physiol 2004, 286:LI 82-LI88. 
2. Heldin $\mathrm{CH}$, Westermark $\mathrm{B}$ : Mechanism of action and in vivo role of platelet-derived growth factor. Physiol Rev 1999, 79: $|283-13| 6$.

13. Abdollahi A, Li M, Ping G, Plathow C, Domhan S, Kiessling F, Lee LB, McMahon G, Grone HJ, Lipson KE, Huber PE: Inhibition of platelet-derived growth factor signaling attenuates pulmonary fibrosis. J Exp Med 2005, 201:925-935.

14. Abdollahi A, Lipson KE, Han X, Krempien R, Trinh T, Weber KJ, Hahnfeldt P, Hlatky L, Debus J, Howlett AR, Huber PE: SU54I6 and SU6668 attenuate the angiogenic effects of radiationinduced tumor cell growth factor production and amplify the direct anti-endothelial action of radiation in vitro. Cancer Res 2003, 63:3755-3763.

15. Luo J, Miller MW: Platelet-derived growth factor-mediated signal transduction underlying astrocyte proliferation: site of ethanol action. J Neurosci 1999, 19:10014-10025.

16. Pierce GF, Vande BJ, Rudolph R, Tarpley J, Mustoe TA: Plateletderived growth factor-BB and transforming growth factor beta I selectively modulate glycosaminoglycans, collagen, and myofibroblasts in excisional wounds. Am J Pathol 1991, I 38:629-646.

17. Shure D, Senior RM, Griffin GL, Deuel TF: PDGF AA homodimers are potent chemoattractants for fibroblasts and neutrophils, and for monocytes activated by lymphocytes or cytokines. Biochem Biophys Res Commun 1992, I 86:1510-1514.

18. Siegbahn A, Hammacher A, Westermark B, Heldin CH: Differential effects of the various isoforms of platelet-derived growth factor on chemotaxis of fibroblasts, monocytes, and granulocytes. J Clin Invest 1990, 85:916-920.

19. Thornton SC, Walsh BJ, Bennett S, Robbins JM, Foulcher E, Morgan GW, Penny $R$, Breit SN: Both in vitro and in vivo irradiation are associated with induction of macrophage-derived fibroblast growth factors. Clin Exp Immunol 1996, I 03:67-73.

20. Tada H, Ogushi F, Tani K, Nishioka Y, Miyata Jy, Sato K, Asano T, Sone S: Increased Binding and Chemotactic Capacities of PDGF-BB on Fibroblasts in Radiation Pneumonitis. Radiation Research 2003, 159:805-8II.

21. Antoniades HN, Bravo MA, Avila RE, Galanopoulos T, Neville-Golden J, Maxwell M, Selman M: Platelet-derived growth factor in idiopathic pulmonary fibrosis. J Clin Invest 1990, 86: I055-1064.

22. Franke TF, Yang SI, Chan TO, Datta K, Kazlauskas A, Morrison DK, Kaplan DR, Tsichlis PN: The protein kinase encoded by the Akt proto-oncogene is a target of the PDGF-activated phosphatidylinositol 3-kinase. Cell 1995, 81:727-736.

23. Canalis E: Effect of platelet-derived growth factor on DNA and protein synthesis in cultured rat calvaria. Metabolism I98I, 30:970-975.

24. Heldin P, Laurent TC, Heldin CH: Effect of growth factors on hyaluronan synthesis in cultured human fibroblasts. Biochem J 1989, 258:919-922.

25. Blatti SP, Foster DN, Ranganathan G, Moses HL, Getz Ml: Induction of fibronectin gene transcription and mRNA is a primary response to growth-factor stimulation of AKR-2B cells. Proc Natl Acad Sci USA 1988, 85: I I I9-I I 23.

26. Fambrough D, McClure K, Kazlauskas A, Lander ES: Diverse signaling pathways activated by growth factor receptors induce broadly overlapping, rather than independent, sets of genes. Cell I999, 97:727-74I.

27. Richeldi L, Davies HR, Ferrara G, Franco F: Corticosteroids for idiopathic pulmonary fibrosis. Cochrane Database Syst Rev 2003:CD002880

28. Savikko J, Taskinen E, Von Willebrand E: Chronic allograft nephropathy is prevented by inhibition of platelet-derived growth factor receptor: tyrosine kinase inhibitors as a potential therapy. Transplantation 2003, 75: I |47-II53.

29. Lang DS, Jorres RA, Mucke M, Siegfried W, Magnussen H: Interactions between human bronchoepithelial cells and lung fibroblasts after ozone exposure in vitro. Toxicol Lett 1998, 9697:13-24.

30. Demayo F, Minoo P, Plopper CG, Schuger L, Shannon J, Torday JS: Mesenchymal-epithelial interactions in lung development and repair: are modeling and remodeling the same process? Am J Physiol Lung Cell Mol Physiol 2002, 283:L5 I0-L5I7.

31. Ward WF, Molteni A, Solliday NH, Jones GE: The relationship between endothelial dysfunction and collagen accumulation in irradiated rat lung. Int J Radiat Oncol Biol Phys 1985 I I:1985-1990.

32. Yamasaki Y, Miyoshi K, Oda N, Watanabe M, Miyake H, Chan J, Wang $X$, Sun L, Tang C, McMahon G, Lipson KE: Weekly dosing with the platelet-derived growth factor receptor tyrosine kinase inhibitor SU95 I 8 significantly inhibits arterial stenosis. Circ Res 200I, 88:630-636.

33. Allen JT, Spiteri MA: Growth factors in idiopathic pulmonary fibrosis: relative roles. Respir Res 2002, 3:13.

34. Battegay EJ, Raines EW, Seifert RA, Bowen-Pope DF, Ross R: TGFbeta induces bimodal proliferation of connective tissue cells via complex control of an autocrine PDGF loop. Cell 1990, 63:5I5-524.

35. Battegay EJ, Raines EW, Colbert T, Ross R: TNF-alpha stimulation of fibroblast proliferation. Dependence on platelet-derived growth factor (PDGF) secretion and alteration of PDGF receptor expression. J Immunol 1995, I 54:6040-6047.

36. Raines EW, Dower SK, Ross R: Interleukin-I mitogenic activity for fibroblasts and smooth muscle cells is due to PDGF-AA. Science 1989, 20(243):393-396.

37. Abdollahi A, Hahnfeldt P, Maercker C, Grone HJ, Debus J, Ansorge W, Folkman J, Hlatky L, Huber PE: Endostatin's antiangiogenic signaling network. Mol Cell 2004, 13:649-663.

38. Abdollahi A, Griggs DW, Zieher H, Roth A, Lipson KE, Saffrich R, Grone HJ, Hallahan DE, Reisfeld RA, Debus J, Niethammer AG, Huber PE: Inhibition of alpha(v)beta3 integrin survival signaling enhances antiangiogenic and antitumor effects of radiotherapy. Clin Cancer Res 2005, I I :6270-6279.

39. Huber PE, Hauser K, Abdollahi A: Genome wide expression profiling of angiogenic signaling and the Heisenberg uncertainty principle. Cell Cycle 2004, 3: |348- I35 |

40. Huber PE, Bischof M, Jenne J, Heiland S, Peschke P, Saffrich R, Grone $\mathrm{HJ}$, Debus J, Lipson KE, Abdollahi A: Trimodal cancer treatment: beneficial effects of combined antiangiogenesis, radiation, and chemotherapy. Cancer Res 2005, 65:3643-3655.

\section{Pre-publication history}

The pre-publication history for this paper can be accessed here:

\section{http://www.biomedcentral.com/1471-2407/6/79/prepub}

Publish with BioMed Central and every scientist can read your work free of charge

"BioMed Central will be the most significant development for disseminating the results of biomedical research in our lifetime. "

Sir Paul Nurse, Cancer Research UK

Your research papers will be:

- available free of charge to the entire biomedical community

- peer reviewed and published immediately upon acceptance

- cited in PubMed and archived on PubMed Central

- yours - you keep the copyright 